\title{
Just Enough English to Get by: Language Practices of Transnational Migrants in Chinese Stores in Cape Town, South Africa
}

\author{
Miché Thompson \\ $\mathrm{PhD}$, Lecturer in Linguistics, Department of African Studies and Linguistics, \\ Faculty of Humanities, University of Cape Town, Cape Town, South Africa \\ miche.thompson@uct.ac.za
}

\begin{abstract}
The presence of a Chinese community in South Africa has become increasingly visible over the last decade, particularly in the trading sector. This is illustrated in the sizable number of new shopping centres settled specifically by groups of Chinese traders, known as China Towns. Shopkeepers and shop assistants come from various linguistic and cultural backgrounds, China and other African countries respectively, but living and working in a multilingual South Africa, they communicate in English, which is the lingua franca. This paper explores their language practices and reflects on a particular language contact situation where shopkeepers and assistants of various migrant origins work closely together. The study adopts a linguistic ethnographic approach to the analysis of the interaction between shopkeepers and assistants and uses conversation analysis to elucidate the ways in which meaning is negotiated and understood in interaction between multilingual speakers. Unscripted audio recorded spoken interaction of the participants throughout the workday is the primary source of data. Additionally, interviews and observational notes are used to supplement the interactional data and illustrate the creative forms of language use that emerge in a in a China Town centre near Cape Town in the Western Cape.
\end{abstract}

\section{Keywords}

China Town - multilingual workplace - repertoires - migration - English Lingua Franca - China - Africa - linguistic ethnography 


\section{Introduction}

South Africa is seen as a destination for many migrants from neighbouring African and Asian countries, and their presence in South Africa has become part of the diverse population of most towns and cities. These migrant communities are particularly represented in large numbers in the informal trading sector (Khosa and Kalitanyi 2014). One particular community that has become well-known for success in establishing such trade occupations and managing them profitably is the Chinese diaspora (Sara 2013). Following its transition to democratic rule in 1994, South Africa saw a significant growth in the number of Chinese migrants entering the country, so that by the end of Apartheid, estimates of a Chinese community ranged from 200 ooo to over 350 ooo ${ }^{1}$ registered and unregistered migrants from mainland China, particularly from Hong Kong (Harris 2007, Huyhn, Park and Chen 2010;). In 2009 the estimated number of the Chinese population on the African continent ranged between 580 ooo and 800 ooo, with South Africa hosting the largest Chinese community on the continent (Park 2009). This is evident in the establishment of new shopping centres settled across South Africa specifically by groups of Chinese traders, known locally as China Towns. Within the last decade, the presence of a Chinese diaspora in the Western Cape has become widely confirmed.

In many parts of the world where Chinese diasporas exist China Towns are enclaves where people of Chinese origin live, work and maintain a relatively close-knit community. South African China Towns, however, refer to a collective of small stores owned and managed by Chinese entrepreneurs who retail made-in-China goods. This is a community of transnational migrants (Vertovec 1999, 2004) that provide mutual support by setting up businesses in proximity of one another. Transnationalism here refers to mobile people whose identities are linked to more than one nation (Vertovec 1999) and accounts for the ways people's practices transcend one or more nations. The Chinese entrepreneurs are therefore not detached from their place of origin, but live their lives in more than one place and participate in processes that transcend borders and create, shape and transform their identities.

The China Town stores in which this study is situated are owned by relatively recently migrated Chinese individuals or families who rent store space in the centre. The shop assistants who are of African migrant origin are all employed on an informal basis with only a verbal agreement between them

1 More recent publications (Liao and He 2015) estimate the number of Chinese in South Africa to be between 300 ooo and 400 ooo. Providing an accurate figure is challenging due to the number of undocumented migrants as well as the mobility of transnational migrants. 
and the shopkeepers. The roles and duties of the shopkeepers and the assistants are specifically predetermined in China Town, and the layout within the stores is similarly patterned. The owners are seated at the point of sale, which is an elevated platform behind a counter with the cash register and in most cases an electronic payment device; while, in addition to assisting customers, the assistants are tasked with unpacking and restocking shelves, cleaning the store, running errands and in some instances tasked with child-care duties.

The shopkeepers and assistants speak different, often mutually unintelligible primary languages, as well as a range of secondary languages, but with individual speaker repertoires (Blommaert 2010, Busch 2012, 2016, Bagga-Gupta and Carneiro 2021) with minimal overlap. For example, Mandarin Chinese, French, Lingala, Swahili, and Ẹdó were identified as primary languages among the participants of this study. These languages are regarded as minority foreign languages in the context of South Africa's National Language Policy Framework (2003). According to the framework approximately 25 indigenous languages are spoken in South Africa, and 11 of these languages have been granted official status. The Western Cape Province uses three of the 11 official languages, namely Afrikaans, English, and isiXhosa. The variety of primary languages within this context emphasises the communicative dependence of this community on a lingua franca. In conformity with the rest of South Africa, the role players in this trading space rely on English as a workplace language, even though they speak different "Englishes" (see Kachru 1992, 1996, also Schneider 2020 for more recent applications) with varying levels of proficiency. Against this backdrop, this paper discusses the practices and strategies of business communication in a China Town shopping centre near Cape Town in the Western Cape. Through the analysis of transcribed audio recorded workplace conversation, observations, and interviews, this paper discusses the value of situated interactional data for understanding communication among speakers with varying language repertoires who have limited command of the local lingua franca.

\section{Problem Statement and Research Question}

This study deals specifically with a language contact situation where migrant groups from considerably different linguistic and cultural backgrounds meet and reflects on how globalisation and migration from the Southern periphery affect language practices in multilingual South Africa. Multilingualism and multilingual practices are evidently characteristic of language contact situations where transnationals meet, or where there are different linguacultural 
allegiances. One domain that has come into focus of late is that of the multilingual workplace. Considerable work has been done on multilingualism and emergent languages in the workplace, such as Otsuji and Pennycook (2010, 2011) and their work on Japanese speakers in the Australian workplace context and Pennycook and Otsuji (2014) on metrolingual francas in the marketplace; Amelina's (2010) multilingual study of Russian speakers in the German workplace; Eley's (2015) linguistic ethnography of multilingualism in a Frankfurt barbershop, and Félix-Brasdefer's (2015) study on service encounters in Mexico and the US. More recently, Kraft (2017) investigated multilingual language practices on a Norwegian construction site, and further study into linguistic practices in these blue-collar spaces was carried out by Lønsmann and Kraft (2018). Although these studies contribute to the conceptualization of multilingualism in various workplaces, their contexts of investigation are positioned in the global North. This paper, however, explores linguistic practices in small-scale Chinese stores situated in China Town in Cape Town South Africa, and reflects on China Town as a particular context of language contact where multilingual speakers of various migrant origin meet. In the context reported on in this paper where the basic workplace requirement is just enough English to get by, the communicative practices differ markedly from those in more sophisticated, institutionalised multilingual workplaces, such as ones dealt with by Roberts (2007) and Amelina (2010) for example.

By adopting a bottom-up perspective to globalisation, this paper centralizes the language practices that happen on the ground where there is language contact and adds to the conversation on how people from the Southern periphery construct their own meaningful voices and create their own linguistic repertoires within globalisation. In this vein, the study addresses one overarching question, namely: what are the characterising features of communicative events in China Town stores where English is used as lingua franca by Mandarin-speaking shopkeepers and shop assistants with an African language as a primary language?

This paper is structured as follows: I will firstly discuss the position of English as a Lingua Franca (henceforth ELF) within current discussions around the sociolinguistic approach to globalisation. Secondly, I explain the methodology, focusing on the data for the study as well as the analytical approach adopted to the analysis of the data. In the section that follows I present and discuss the data analysis of linguistic practices in two stores as well as findings from ethnographic observations and interviews. Finally, the paper concludes with a discussion of the main findings. 


\section{ELF and Globalisation}

There is an undeniable gap in the conceptualisation of globalisation as a socio-cultural phenomenon and in theories of globalisation in relation to sociolinguistics. Perceptions of globalisation as a concept are prevalent as a notion of "an immense, unstructured, free unbounded space and of a glorious, complex mixity" (Massey 1999:34). This interconnection and interdependence pose a need for a more complex engagement with globalisation as both a process and a phenomenon that goes beyond political, economic, and geographical connections. In this vein Blommaert, Collins and Slembrouck (2005) posit that globalisation phenomena forces us to seek a better integration of sociolinguistics. Given that globalisation is non-linear and is not uniformly or universally experienced (Coupland 2010) it is more suitably theorised from a sociolinguistic standpoint as the complex connections where the local and the global intersect. Rassool (2003:38) adds to the sociolinguistic complexity of globalisation contending that on the one hand it addresses a carefree multilingual cosmopolitanism and, on the other, the hegemony of English as international lingua franca. Moreover, due to globalisation and the development of technology including digital communications technologies English has become the de facto language of wider communication on a global scale, albeit in different varieties (see Mesthrie and Bhatt 2008). Blommaert (2010) concurs that the traditional concept of language continues to be dislodged and destabilized by globalisation; and new societal needs result in a change in how we use language and in how we understand language. The complexities of the processes associated with globalisation thus have implications for the way we understand language (Dewey and Jenkins 2010:77). In this view, globalisation is as much a sociocultural and sociolinguistic phenomenon as it is an economic, political, and migratory one.

Following Jacquemet's (2005) call for studies on the global phenomenon of language contact this paper takes its departure from Blommaert et al. (2005) and shows how mobile people in situations of language contact deal with the linguistic demands of a globalising world. The development of a sociolinguisticglobalisation research corpus proves that if different conceptualisations of globalisation are discussed it opens up dialogue for the discussions of World Englishes and debates around ELF. Dewey (2007:349) thus proposes an integration of globalisation and ELF studies:

To discuss the various means of conceptualizing globalisation is to better comprehend the World Englishes and ELF arguments, and better understand how the current transformations English is undergoing are part of 
far broader global trends. Acknowledging the increased cultural flows so prominent in the contemporary world order adds significant weight to any discussion of why and how innovative linguistic forms are emerging in ELF.

ELF, as it is used in this study, is taken to be a creative and versatile frame of communication that allows a level of mutually understandable interaction to occur where speakers do not share a common language repertoire. House (2003) explains that ELF is neither a pidgin, nor a language restricted for specific purposes, but rather a language of wider communication which draws on the repertoires of instruments that speakers have at their disposal, and that has full functional and linguistic range, which allows for contact between people who do not share the same primary language. Sewell (2013:7) emphasises that there is a connection between studies in ELF and the interest in dynamic and emergent language practices as a social phenomenon. In this vein, Seidlhofer (2009) in describing the innovative process of ELF communication, likens it to 'languaging' (see Swain 2006) which relates to the way speakers use linguistic resources to meet communicative ends. Language thus becomes something that people do rather than something that exists externally.

Most influential studies in ELF stem from within the European or business contexts (for example Firth 1996, Cogo 2012, Franceschi 2017) and institutional academic settings (for example Smit 2010a, 2010b; House 2013, Negretti and Garcia-Yeste 2015) which creates a need for studies in ELF from the global South in less formal spaces. The need to illustrate innovative emerging linguistic forms in grassroots contexts is motivated by Rassool (2003:41) who puts forward that owing to the intensification of interactivity within globalisation, contradictory and oppositional voices are active and valorised while others are systematically silenced within the processes of globalisation. This leads one to consider whether globalisation equates to Englishisation, and whether certain languages and their subsequent varieties that are not ideologically or politically valued globally face the risk of being silenced through shift or endangerment (see Mufwene \& Vigoruroux, 2008). Thus, questions of ELF and how it is different from other English varieties are a major ontological issue within the conversation on English as a global language (Jenkins 2006, Dewey and Jenkins 2010, Sowden 2012). Sewell (2013:6) notes this criticism, contending that the "tendency to reify ELF, and juxtapose it with an equally reified model of ENL [English as a native language], is a seemingly unavoidable aspect of ELF discourse." Seidlhofer (2009:242) opposes this comparative view, noting that ELF speakers are goal orientated in the interaction and are focused on their interlocutors as people, and emphatically not on the linguistic code itself. 
Hülmbauer et al. (2008) maintain that ELF users should be conceptualised as a community of practice, as their mutual engagement repertoire does not come from a shared language but rather a shared variety. Ehrenreich (2017) citing Wenger (1998) similarly asserts that when conceptualising ELF speakers as a community of practice, three criterial features are present, namely mutual engagement, a joint enterprise, and a shared repertoire. This is further confirmed by scholars such as Hülmbauer et al. (2008) who emphasise the collaborative, cooperative and consensus-oriented nature of lingua franca discourse. Each of these dimensions is realised in ELF-based communities of practice.

The pragmatic interest in lingua franca studies is on how speakers appropriate their primary languages and all other languages in their repertoire to meet the communicative needs of the situation. The aim of ELF is ultimately not to learn or mimic an "acceptable" form of English, but to achieve efficient communication that results in mutual understanding. Cogo (2012:283) concurs, noting that ELF is not a stable system that exists outside of language use, but that it is "shaped by practice, shared and co-constructed by users themselves, and contingent to its communities of practice." This is evident in studies like Han's (2013) work on the language practices in an African marketplace in Guangzhou China and provides a sense of optimism to the emergent language practices that stem from contact situations. In what she refers to as "grassroots multilingualism" Han found that African migrants and native Chinese developed a lingua franca, coined "Chinglish", which describes an emergent hybridised Chinese-English mutual linguistic code. The emergence of "Chinglish" as a lingua franca is characteristic of a language contact situation that constitutes transnational or migrant people, participating in deterritorialized processes (Jaquemet 2005), using language creatively in a way that is neither characteristic of standard language varieties nor that implicates their primary language. This speaks to Firth's (2009:148) prediction that particular ('non-native') varieties of English may be emerging.

Studies like Han's are of course significantly context-dependent and the linguistic ecology in which these interactions occur need to be taken into account. This is echoed by Pölzl and Seidlhofer (2006) who identify the context factor as a significant catalyst for cultural transfer within ELF interactions, and they maintain that the physical context is an influencing factor in determining how speakers perceive the interaction. Continuing from the suggestion of Pölzl and Seidlhofer (2006:172) that "norms for pragmatic fluency are highly context dependent" this study pays careful attention to the effects of the locus of interaction on the speakers by adopting a linguistic ethnographic approach to the analysis of lingua franca interaction. 
In this vein China Town is conceptualised as a site of ELF communication; as a contact zone of transnational and diasporic communities. This research does not primarily look at the linguistic features identified in English lingua franca interactions, but focuses more specifically on the various functions that English lingua franca fulfils in the linguistic practices that are observed.

\section{Methodology}

This study is a Linguistic Ethnography which draws on Gumperz's (2001) Interactional Sociolinguistic (henceforth Is) approach to the analysis of interaction. The premise of Is according to Gumperz (2001:216) is that "to look at talk as it occurs in speech events is to look at communicative practices." Linguistic Ethnography (LE) and Interactional Sociolinguistics (IS) are two closely related perspectives, and LE emerged as a branch of IS. LE is a recent development that has been influenced by linguistic anthropological traditions such as Hymes' $(1968,1972)$ ethnography of communication, Gumperz's (1972, 1982, 2001) interactional sociolinguistics, and Erickson's micro-ethnography (1996). LE deals with contextually situated communication "that pays particular attention to the efforts individuals make to get other people to recognise their feelings, perceptions, interests, etc." (Rampton 2007:3). This approach is significantly contextual and focuses on "situations of speaking" by utilising ethnographic methods of inquiry. Rampton (2007) advocates for LE in sociolinguistics, contending that the interactional context should be investigated alongside the interactional data, and that LE provides a view into the context of communication. This is also echoed by Bagga-Gupta and Carneiro (2021) who argue that the semiotic resources that are at play in contexts of communicative practices should be carefully considered and not taken for granted (Bagga-Gupta and Carneiro 2021:325).

Creese (2008:231) conceptualises Is as "concerned with intercultural encounters and the systematic differences in the cultural assumptions and patterns of linguistic behaviour which are considered normal by those involved." Rampton (2007) further states that people, situated encounters and institutions are interconnected, and LE provides an approach that explains these links. In a similar vein Ehrenreich (2017:38) adds that within the social context of ELF interactions one can identify and describe "group-internal social parameters" that allow one to understand the communicative behaviour of the community. Looking specifically at the concept of repertoires, Bagga-Gupta and Carneiro (2021) argue that the current conceptualisation of repertoires needs to move 
away from looking at language as "countable fixed resources" and that there is a need for careful consideration of the multimodality and multisemioticity in communicative practices and the contexts in which they take place (Bagga-Gupta and Carneiro 2021:326-327). Following this, Cogo (2012) advocates for a research approach that provides an emic perspective to situations of ELF in use. By employing LE as a "strong ethnographic element" (Seidlhofer, Breiteneder \& Pitzl 2006: 21) this research sought to examine social, semiotic, and contextual facets within this community of practice.

IS also draws on Conversation Analysis (CA) as one of its analytical resources, as CA provides tools for the micro-analysis of meaning-making in situated encounters. In further utilising an emic perspective to uncover the underlying principles of interaction, this study uses CA for the analysis of situated talk (Schegloff 1987, 1988, Drew 2005, Heritage 2005). Firth motivates for the use of CA in ELF research, contending that when ELF communication as data is addressed from a CA perspective, it contributes to an understanding of the nature of conversational competence as well as the linguistic and interactional resources used for participants to achieve meaningful communication (Firth 1996:240). Ehrenreich (2017:45) further adds that qualitative ethnographic approaches in conjunction with discourse analysis or CA methods are a promising way to capture the multidimensionality of ELF in use.

\section{The Data}

The data in this study comprises audio recorded unscripted conversations between shopkeepers and assistants in stores throughout the workday and includes interview data and field notes from participant observation during the data collection. Participants wore portable voice recorders and the recorded interaction comprise the primary data for this study. These recordings were later transcribed, and the transcriptions were integrated with the observational field notes and subsequently analysed. The transcription follows a simplified version of traditional cA conventions (see appendix attached).

Overall, roughly 48 hours of spontaneous interactions were recorded across a period of six weeks, and observation were done over a period of three months. This fieldwork involved sitting in the stores throughout the workday, observing interactions and noting contextual information pertaining to these interactions. The motivation for the triangulated methodology is summarised by Nickerson (2005:371) who notes that "communicative events are considerably more complex than the label of English as a lingua franca would suggest." 
Triangulation of data collection methods thus addresses this complexity. With this in mind the data demonstrates the kinds of linguistic practices produced in two stores where recordings took place, with a focus on how they use English as the language of wider communication and which specific conversational strategies develop as generic means of workplace interaction. Excerpts from interviews conducted in non-participating stores with shopkeepers are also included in this study.

\section{The Stores}

Conversational data was collected in two stores: one retailing in lingerie and bathing suits, and the other retailing in fashion clothing, shoes and accessories. Chinese stores generally retail in made-in-China goods, particularly clothing, electronics, toys and homeware. The layout of stores in China Town, and Chinese stores in general, as observational data has shown, are all spatially similar. Stores are small, ranging between $50-80$ square meters and are characterised by narrow aisles, densely packed with items (see fig.1 below). The

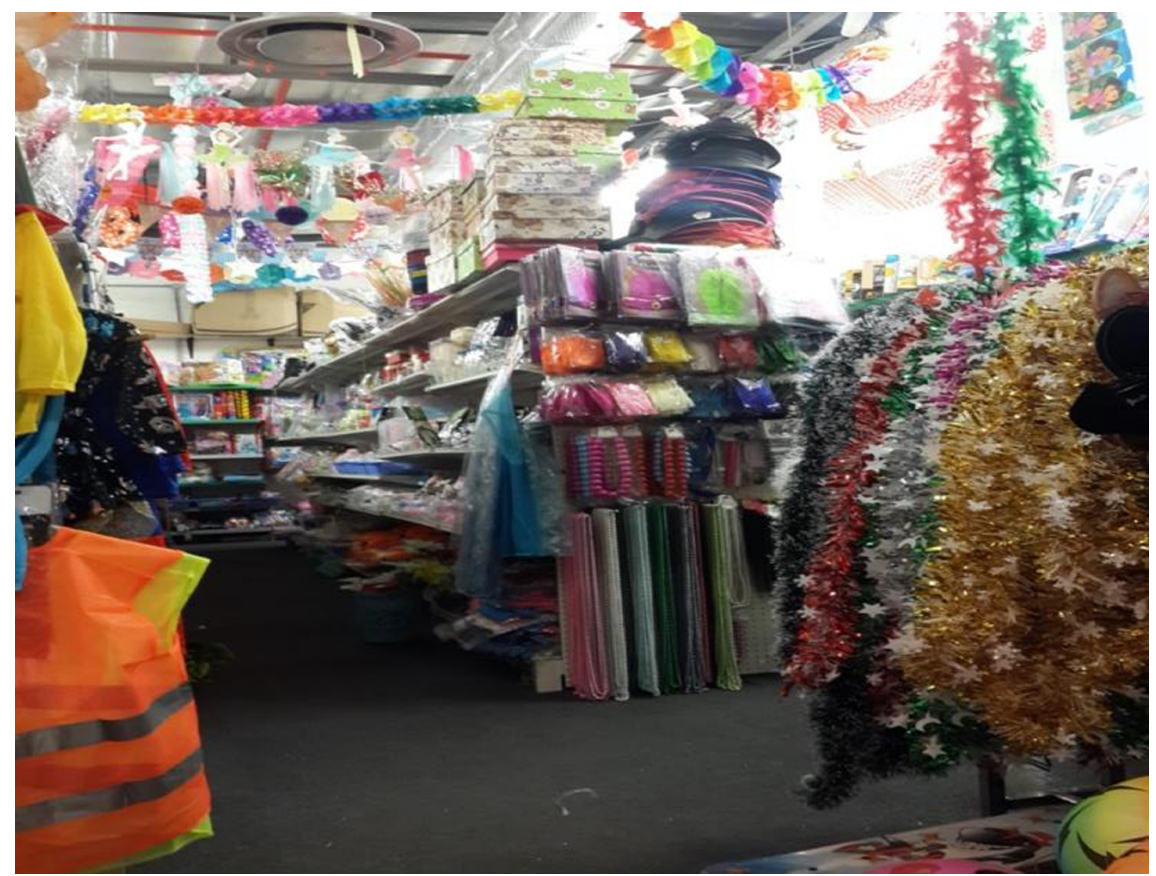

FIGURE 1 A store selling toys, costumes, and party decorations 
shop keepers are positioned on an elevated platform which serves as the point of sale and is usually set up at the entrance/exit in order to monitor customer activity. Stores are so compact that regardless of where I was positioned as an observer, I was still able to observe all interaction and activities that occurred during the workday.

\section{The Participants}

The participant population presented in this study comprised four shopkeepers and four shop assistants. A brief overview of the participants and their self-reported language repertoires, in various proficiencies (see Blommaert 2010) are illustrated in the table below.

TABLE 1 Participants and their linguistic repertoires

\begin{tabular}{|c|c|c|c|}
\hline Participants & $\begin{array}{l}\text { Role in China } \\
\text { Town }\end{array}$ & Language repertoire & Place of origin \\
\hline $\mathrm{N}:$ & assistant & $\begin{array}{l}\text { Swahili, French, Tshiluba, } \\
\text { Lingala, English, Mandarin } \\
\text { Chinese, isiXhosa, Afrikaans }\end{array}$ & Lubumbashi DRC \\
\hline S: & assistant & $\begin{array}{l}\text { Swahili, French, Lingala, } \\
\text { English, Mandarin Chinese, } \\
\text { isiXhosa, Afrikaans }\end{array}$ & Kinshasa DRC \\
\hline $\mathrm{F}:$ & assistant & English, Ẹ̀dó & Benin Nigeria \\
\hline G: & assistant & $\begin{array}{l}\text { English, Lingala, French, } \\
\text { Mandarin Chinese, isiXhosa, } \\
\text { Afrikaans }\end{array}$ & Kinshasa DRC \\
\hline su: & shopkeeper & Mandarin Chinese & $\begin{array}{l}\text { Shaanxi Province } \\
\text { China }\end{array}$ \\
\hline NW: & shopkeeper & $\begin{array}{l}\text { Mandarin Chinese, English, } \\
\text { isiXhosa }\end{array}$ & $\begin{array}{l}\text { Fujian Province } \\
\text { China }\end{array}$ \\
\hline IR: & shopkeeper & Mandarin Chinese & Lijiang City China \\
\hline сн: & shopkeeper & $\begin{array}{l}\text { Mandarin Chinese, } \\
\text { Cantonese, English }\end{array}$ & Taiwan \\
\hline
\end{tabular}




\section{Ethical Considerations}

Access to the stores was obtained by approaching shopkeepers and assistants, and data was collected only once informed consent was obtained from all participants. For the interviews, a Chinese Mandarin-speaking research assistant who was an undergraduate Linguistics student, explained the aims and objectives of the project to the shopkeepers in Mandarin, and consent forms with details of the project were also provided in Mandarin. I conducted the interviews with shopkeepers in English and the research assistant translated the questions to Mandarin in real time. The interview responses were later translated to English and transcribed by the research assistant. For the recording of unscripted workplace conversations and observational data, consent forms were provided in English, French, and Mandarin, and I further explained the details of the project in English. Participants could choose their own pseudonyms. To ensure confidentiality the participants and the research site have been anonymised in this paper.

\section{Complexity of Communication Practices: Data Analysis}

This section presents an analysis of data which consists of observational findings from fieldwork, excerpts from interviews, and data from spontaneous workplace interaction in order to describe the complexity that is the communicative practices in China Town. Following Rampton's (2007) suggestion that people, situated encounters and institutions are interconnected, this section presents a holistic approach to the analysis of the data. Significantly, this section overall shows how ELF communication is notably successful despite the variability in participants' linguistic repertoires.

\section{Functionality of Language}

Customers who shop in China Town are local and migrant people who live in the surrounding communities in which this shopping centre is located. Since this China Town is the only one of its kind in this particular suburb, it attracts a variety of people from lower- and working-class communities. Local customers comprise the majority of the clientele and observational data has shown that very little communication takes place between shopkeepers and these customers. This is likely due to the self-service nature of the stores: customers browse through narrow aisles often under the surveillance of security cameras 
or the shop assistants, and only initiate interaction when they need assistance. In other instances, they enter the stores, browse, and if they don't make a purchase, they exit without initiating interaction with either shopkeeper or the assistant. The observational data has shown that if customers want to enquire the price of an item, they hold up the item in the direction of the shopkeeper and ask, "how much?", to which the shopkeeper would provide the price. If customers required assistance with finding a specific colour, size or style in a garment or item, it was evident that shop assistants were employed for the primary purpose of communicating with and assisting customers in ways that the shop owner could not. A basic proficiency in English, enough to facilitate the sale of a product, is a job requirement for the assistants. When they are not assisting customers, assistants converse in their respective primary languages, and shopkeepers occupy their time with Chinese television series, mobile games, and conversations with other shopkeepers.

The shop assistants in this study are all multilingual and speak English as an additional language. S, for example, had no prior instruction in English and learned the language when she came to South Africa in search of career opportunities when she arrived here in 2012. She learned English as a functional language in interaction with customers in China Town and in other domains such as television media. This basic proficiency is functional within the workplace, and often not used to interact outside of sales talk. It has been observed that assistants speak to one another in their primary languages (usually Lingala or chiShona) and only switch to English in interaction with customers or shopkeepers. This is expressed in an interview by F, who speaks Ẹdó, a language not commonly spoken in South Africa since most Nigerian migrants in South Africa speak Yorùbá or Ásụ̀sụ̀ İgbò. She explains the difficulty she experiences when she tries to befriend shop assistants in other stores:

Sometimes I want to be friends with them, [and I speak] just English. 'Hello,'Good morning'. I sometimes speak then they say 'oh come again come again'. You know their English is mixed with their own language.

Observational and interview data has shown that the employment of shop assistants mitigates the need for shopkeepers to communicate with customers. This was expressed by NW when asked in an interview whether he has ever needed an interpreter when dealing with customers. He reported that he would only need interpretation when there is a communication breakdown between himself and a customer. In such an event he would not resort to an external or mobile translator (such as Google translate for example) but would call on one of the assistants to broker the interaction. He explains: 
I just uh say 'I don't understand what'... then you just uh call those [assistants], call you see $\mathrm{N}$ come or call them.

When prompted with the same question on communicative breakdown with customers, $\mathrm{CH}$ responds:

If they don't understand we can call the [assistant] lady to help

Significantly, the assistants are often less proficient than the shopkeepers, as in CH's case. CH speaks semi-fluent English and has lived in South Africa for over 25 years, yet he still employed an assistant to assist with customers' needs. Although language barriers still appear to be present in China Town, it does not seem to be problematic for either shopkeepers or customers. Shopkeepers give customers their space to browse the stores and seek no interactions; and customers tend to seek no interaction from the shopkeepers. If interaction is needed, the assistants would step in to assist and facilitate the sale. Communication between trader and customer in this context is functionally oriented rather than interpersonal.

\section{Self-perceived Communicative Needs: a Focus on the Products}

Given the limited focus that is placed on interaction with customers in their stores, I asked shopkeepers to reflect on their general interaction with customers, which was aimed at determining how much value they place on language for the success of their business. Overwhelmingly, shopkeepers emphasised the importance of their products, and language was depicted as a secondary factor to the success of a sale. When asked how she communicates with customers who enter her store, IR states:

Well, I price all the products in the shop. If customers like it, they will buy.

A follow-up question enquired into the kinds of communicative strategies might be used to make customers feel welcome in her store. The response was:

When they ask me I will answer.

From this excerpt it is clear that the focus is on the product and not on interaction with customers. IR's response clearly illustrates that there is not a need for communication as long as customers have access to the products. A similar 
sentiment was expressed by $\mathrm{CH}$. The interview question specifically asked "how would you describe the interaction with customers? From the moment they enter the store, how would you interact with them?". And to this $\mathrm{CH}$ who is a semi-fluent English speaker responded:

\section{Uuh...Uh...your product.}

This shows that even when shopkeepers are able to communicate in the local lingua franca, language is not deemed paramount to the success of their enterprise. If the products are displayed and priced visibly (see fig. 2 and fig. 3 below), not a great deal of communication is required. Interaction between shopkeeper and customer would often occur only at the point of sale when the trade is made, and even then, the interaction is often non-verbal, consisting of set schema of the social roles for this context: the shopkeeper takes the payment, the customer receives their goods, and the customer leaves the store.

\section{Features of Shopkeeper-assistant Workplace Interactions}

Communication between the shopkeepers and assistants themselves presented interesting features. The shop assistants in many instances accommodate the

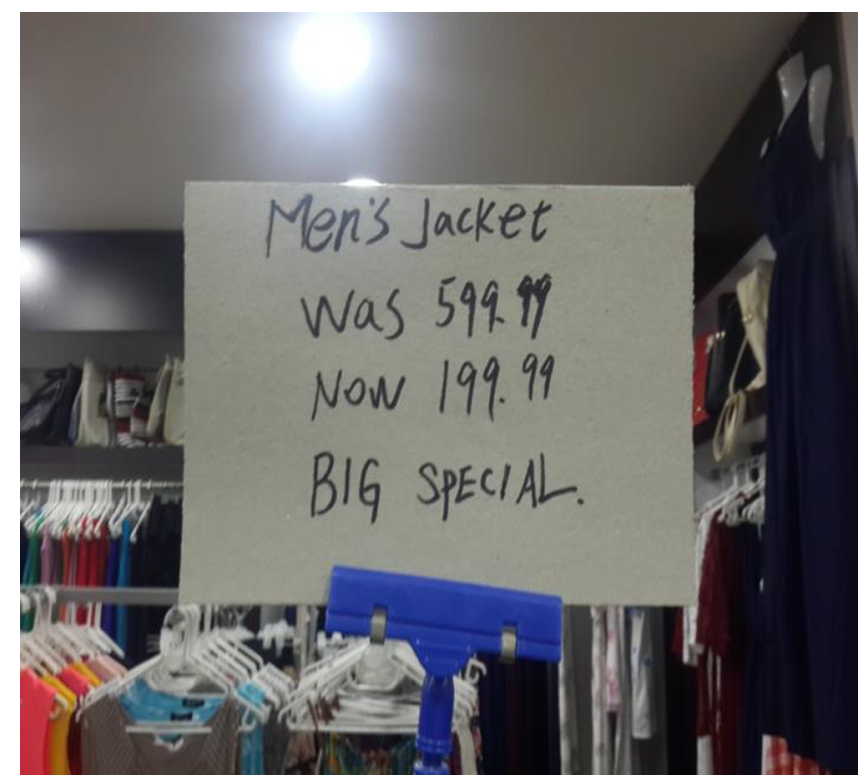

FIGURE 2 Pricing signage in stores 


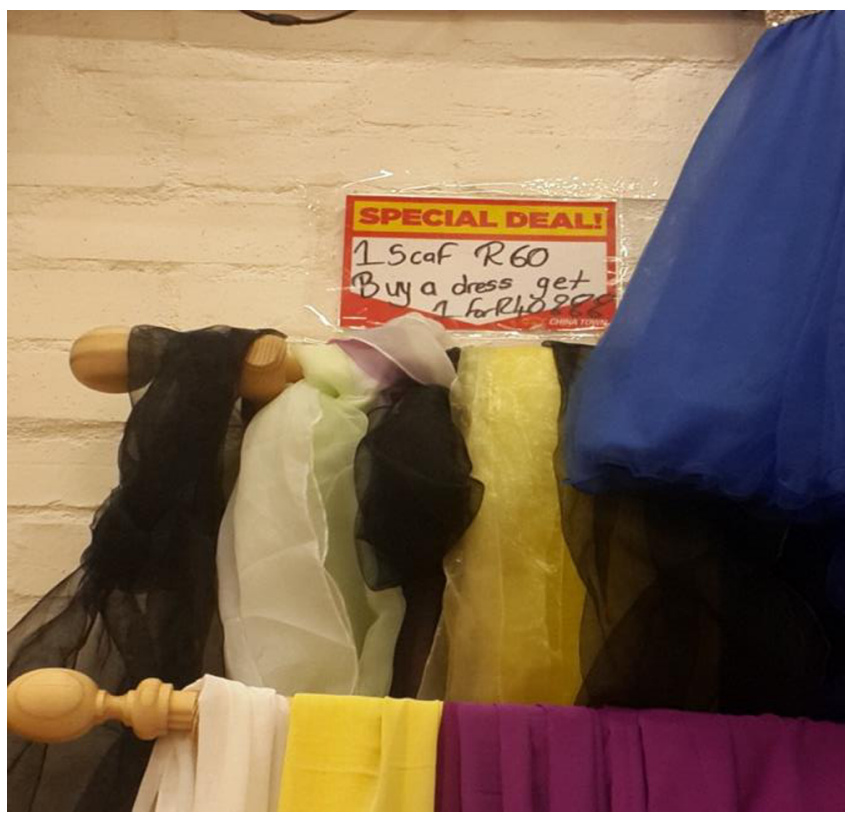

FIGURE 3 Pricing signage in stores

linguistic repertoires of the shopkeepers in order to facilitate successful communication. In an unstructured interview with $\mathrm{F}$ who is an assistant in a lingerie store owned and managed by $\mathrm{SU}$, the point that is raised concerns the interactive work that is put into ensuring successful workplace conversation. When asked to describe communication with her employer, F explains:

She tries to use English to communicate, but the way she presents her English you know sometimes I have to [say] like 'oh I don't understand'. So so there's a way we now communicate now, if I want to say 'I am talking to you' [I say] 'my talk to you'. I don't know if you understand. So not 'I am talking to you now' 'my' means 'I am'. So 'my want to go' is myself. 'My want to buy something' something like that. I don't know if you understand. So that's the only way.

F explained the adaptation process, saying that she uses ' $m y$ ' instead of first-person subject ' $I$ ' or 'I am', and 'mine' instead of the object form ' $m e$ '. $\mathrm{F}$ is the only participant who has had English as medium of instruction when she studied in Nigeria, and thus can confidently interact with customers in English. As the more proficient one in English, F wields communicative power: she interprets for su and is responsible for all the sales talk in the shop. She 
puts considerable effort into following su's variety of English and even reduces the grammaticality of her own English to accommodate su's communicative style. The following excerpt illustrates how an instruction to unpack and clean clothing rails is given and negotiated.

o1 SU: You maybe pack this take off pack this puty inside too much (...) you take it off clean

O2 clean (...) too many dirty.

o3 F: Dust.

O4 SU: Okay

O5 F: Hmmmm.

o6 su: Put water there my see all there

o7 F: Not too dirty. (o.5) Not t个oo dirty so no put water.

o8 Su: No water

og F: No no put water I remove all this ones

10 SU: Hmmm

This interaction follows a turn-by turn sequence characterised by an opening instruction (line $01-02$ ), a subsequent repair of the opening utterance (line 03), a passing over of the repair (line 04), and a final agreement to execute the instruction (line o5) from the opening turn. su opens the interaction sequence by telling $\mathrm{F}$ to unpack the clothing rails and clean them because they are dirty. F repairs su's reference to "too many dirty" (line o2) by responding with "dust" (line o3). su's "okay?" (line 04 ) is a confirming move to ascertain whether her instruction has been acknowledged, ignoring the repair and thus following a common ELF move to "let it pass" (Firth 1996). su moves onto the next instruction by telling $\mathrm{F}$ to use water to clean the rails because she can see the dust that has accumulated: "my see all there" (line o6). F does not take up this instruction, explaining that because the rail is "not too dirty" so she will not use water (line 07 ). su checks and confirms with "no water" and F confirms that she will not use water but will still remove the dust from the rails. Here an instruction from the employer was negotiated and resulted in consensus despite the linguistic repertoire.

In the extract below, $\mathrm{N}$ is packing new clothing items onto the shelves and notices that one particular item is nearly sold out. She brings this to her employer's attention.

O1 N: NW?

O2 NW: What wrong?

o3 N: When will you stock this one? 
O4 NW: Heh?

o5 N: I like it this one.

o6 NW: Bring more?

o7 N:Y个aaaa! People $1 \uparrow$ ike it you ask me 'bring more?'. o8 Nw: Sunday.

Once again, the interaction in this store follows a turn-by-turn sequence, initiated by an opening sequence (line o1), followed by a question-and-answer sequence (lines $02-07$ ) and ending in a resolution to the problem that was raised (line o8). $\mathrm{N}$ opens the interaction by calling to NW's attention (line o1). He registers her utterance with "what wrong?" (line 02 ). $\mathrm{N}$ immediately moves onto the crux of the interaction, asking $\mathrm{NW}$ when he will order more of the clothing items that she is unpacking (line o3). NW's need for clarification (line o4) is met with additional information, that $\mathrm{N}$ likes that particular item and style of clothing (line o5). When asked whether he should order more (line o6), she responds saying that the customers like the item so there should not be a question about whether or not to order more of them (line o7). He registers this and confirms that he will order more of the items on Sunday, effectively closing the interaction (line o8). However brief, this interaction accomplished two things: the first is that the shop assistant informed the shopkeeper that a particular item was selling well, and the second is that the ordering of new stock was initiated and confirmed.

The final extract below depicts a casual conversation between SU and G. SU initiates a conversation about G's education, encouraging her to pursue tuition at university.

o1 SU: You go to Stellenbosch uh the one you

o2 G: =You you pick my money my go

o3 Su: Wh个ere my give you money you! The [one your father].

o4 G: [SU noooo!] ;)

o5 SU: My daughter is uh the one study th $\uparrow$ is uh my pay

o6 G: My also know my go Stellenbosch my study I know

o7 SU: Your one father only buy house the one no gave you [money is the one]

o8 G: [H个eeey su leave me alone]

og SU: You study is good uh the one it's maybe you the one earn money you up up up

10 G: Ya my know

$11 \mathrm{SU}$ : You know?

$12 \mathrm{G}$ : Y个eees! 
A gloss overview of the above interaction proves difficult to make sense of for a first-time reader, but observational notes and contextual information allow for interpretation of the excerpt. In this excerpt su opens the conversation by telling $\mathrm{G}$ that she should apply to study at Stellenbosch University (line o1). G registers su's turn and tells her that if su pays for her tuition she would gladly study (line 02 ). su retorts that G's father should be responsible for the payment, and further clarifies that she pays for her daughter's tuition fees as this is her responsibility (line 03 and 05 ). G does not react to this topic, but instead continues to insist that she could pursue tertiary education if she wanted to (line o6). su continues to insist that G's father should be responsible for her tuition (line o7), to which G light-heartedly tells su to leave her alone, signalling that she is not comfortable with the topic (line o8). su continues that studying will allow $\mathrm{G}$ to earn more money and "move up" in life (line o9). G confirms that she knows (line 10), which su checks: "you know?" (line11). When G exclaims "yeees!" (line 12) she effectively closes the conversation.

In this interaction, two overlaps occur, which is uncharacteristic within this context given that interlocutors have to put in considerably more effort to negotiate meaning. In the other extracts minimal overlaps and interruptions in conversation occur, and participants follow a turn-by-turn sequence to ensure that meaning is understood and tasks are executed. In the casual conversation between $\mathrm{G}$ and su however, the topic is not work-related which means that potential breakdown in meaning is non-essential to the enterprise. Ordinarily interlocutors carefully construct their utterances. This is expressed by $G$ in an unstructured interview when she refers to the way she and su speak as "turning their words around", confirming Firth's (1996:238) position that "the 'normal' and 'routine' appearances of talk are the result of the participants' ceaseless and contingent application of complex though methodic practices." These methodic practices were evident in the way the participants did interactional work to achieve a shared understanding of the conversational goals.

\section{Conclusion}

The overall language practices suggest that due to shared interests in the success of the business, employers and employees who have extremely different linguistic repertoires and limited proficiency in a lingua franca as strong as English, do not consider these as insurmountable impediments to getting the job done of running a store, selling their goods, and keeping the enterprise 
profitable. This speaks to the collaborative, cooperative and consensusoriented nature of lingua franca discourse (Hülmbauer et al. 2008). The interaction sequences are task-driven, save for instances of casual conversation. Even so, overlaps, interruptions and disagreements are minimal, and meaning is negotiated albeit with variable and "truncated" repertoires (Blommaert 2010). Speakers put in collaborative interactive work, following turn-taking sequences and rely on confirming and registering moves within the conversation. Instances of repair are minimal and when they occur, they are passed over as inconsequential to the communicative intent.

"Turning their words around" and the accommodation of interlocutors' languaging show that ELF is mostly functional and goal-orientated in this context and is in no way meant to model native English varieties. Seidlhofer's (2009) position that ELF speakers are goal orientated in the interaction and are focused on their interlocutors as people, and emphatically not on the linguistic code itself is evident here. Additionally, language does not seem to be deemed as significant as initially expected in this context, as indicated by the shopkeepers and their emphasis on the importance of their products rather than customer service. Customer service is a delegated task and is limited to assisting with the trying on of clothing, providing various sizes, colours or prices in items on request, which in itself does not require a great deal of spoken communication from the assistants.

What is most evident is how English is maintained as the language to fulfil only specific workplace functions, and further not used outside of the context of employer-employee or employee-customer interaction. F's account of her difficulty with making friends who speak English in China Town attests to this. This speaks to a notion of assistants having adequate proficiency in a variety of English to fulfil a job requirement, but not for social use outside of China Town as a work domain.

The study forms part of a larger research interest in the languages of migrant communities and how their repertoires facilitate or impede integration into the receiving community. The study not only describes and explain patterns of lingua franca communication; it also reflects on a particular kind of language contact situation and contributes to an understanding of how groups with vastly different first languages and communicative cultures, manage language contact in the informal workplace. With audio-recorded spoken interaction of the participants throughout the workday as the primary source of data, aligned with field notes and observations, this study illustrates the forms of language use that emerge in a grassroots multilingual workplace where various nonmutually intelligible languages are present. Communication between the shop owners and their assistants is shown to portray the kind of language contact 
phenomena that typically develop in informal workplaces where there is an apparent need for a common trade language.

\section{References}

Amelina, Maria (2010). “Do Other Languages Than English Matter?” In Multilingualism at Work: From Policies to Practices in Public, Medical and Business Settings edited by Bernd. Meyer \& Birgit Apfelbaum. (Pp. 235-252). Amsterdam: John Benjamins.

Bagga-Gupta, S. \& Carneiro, A. (2021). "Commentary: Nodal frontlines and multisidedness. Contemporary multilingual scholarship and beyond". International Journal of Multilingualism 18 (2): 320-334.

Blommaert, Jan (2010). The Sociolinguistics of Globalisation. Cambridge: Cambridge University Press.

Blommaert, Jan, James Collins, and Stef Slembrouck, S. (2005). "Spaces of multilingualism". Language and Communication. 25(3):197-216.

Busch, Brigitta (2012). "The Linguistic Repertoire Revisited." Applied Linguistics. 33(5): 503-523.

Busch, Brigitta (2016). Methodology in Biographical Approaches in Applied Linguistics (Working Papers in Urban Language and Literacies No. 187). London: Centre for Language Discourse and Communication, King's College London.

Cogo, Alessia (2012). "ELF and Super-Diversity: A Case Study of ELF Multilingual Practices from a Business Context." Journal of English as a Lingua Franca. 1-2 (2012): 287-313.

Coupland, Nikolas (2010). The Handbook of Globalisation. London: Wiley-Blackwell.

Creese, Angela (2008). "Linguistic Ethnography". In Encyclopeda Of Language Education edited by Kendall King \& Nancy Hornberger. (Pp. 229-41). New York: Springer Science.

Dewey, Martin (2007). "English as Lingua Franca and Globalisation: An interconnected Perspective”. International Journal of Applied Linguistics. 17(3): 332-354.

Dewey, Martin and Jennifer Jenkins (2010). "English as a Lingua Franca in The Global Context." In Contending with Globalisation in World Englishes edited by Mukul Saxena and Tope Omoniyi. (Pp. 72-92). Bristol and New York: Multilingual Matters. Drew, Paul (2005). "Conversation Analysis." In Handbook of Language and Social Interaction Kristin L. Fitch and Robert E Sanders, (Pp. 71-102). London: Lawrence Erlbaum Associates Publishers.

Ehrenreich, Susanne (2017). "Communities of Practice and English as a Lingua Franca." In The Routledge Handbook of English as a Lingua Franca edited by Jennifer Jenkins, Will Baker, Martin Dewey, (Pp. 37-50). London: Routledge. 
Eley, Louise (2015). A Micro-Ecology of Language in Multi-Ethnic Frankfurt: The Linguistic Ethnography of A Barbershop (Working Papers in Urban Language and Literacies No. 155). London: Centre for Language Discourse and Communication, King's College London.

Erickson, Frederick (1996). "Ethnographic Microanalysis." In Sociolinguistics and Language Teaching edited by Sandra L. McKay \& Nancy H. Hornberger, (Pp. 283306). New York: Cambridge University Press.

Félix-Brasdefer, J. César (2015). The Language of Service Encounters. Cambridge: Cambridge University Press.

Firth, Alan (1996). “The Discursive Accomplishment of Normality. On 'Lingua Franca' English and Conversation Analysis." Journal of Pragmatics. 26 (2): 237-259.

Firth, Alan (2009). “The Lingua Franca Factor.” Intercultural Pragmatics. 6 (2):147-170. Franceschi, Valeria (2017). "Plurilingual Resources as an Asset in ELF Business Interactions." Journal of English as a Lingua Franca. 6 (1):57-81.

Gumperz, John J (1972). "Sociolinguistics and Communication in Small Groups." In Sociolinguistics edited by John B. Pride and Janet Holmes, (Pp. 203-224). Harmondsworth: Penguin.

Gumperz, John J (1982). Discourse Strategies. Cambridge: Cambridge University Press. Gumperz, John J (2001). “Interactional Sociolinguistics: A Personal Perspective." In The Handbook of Discourse Analysis edited by Deborah Schiffrin, Deborah Tannen \& Heidi E. Hamilton, (Pp. 215-228). USA: Blackwell Publishers.

Han, Huamei (2013). "Individual Grassroots Multilingualism in Africa Town in Guangzhou: The Role of States in Globalization." International Multilingual Research Journal. 7 (1): 83-97.

Harris, Karen, L (2007). "Waves of Migration: A Brief Outline of the History of Chinese in South Africa." China Monitor. 21:4-5.

Heritage, John (2005). "Conversation Analysis and Institutional Talk." In Handbook of Language and Social Interaction edited by Kristin L. Fitch \& Robert E. Sanders, (Pp. 103-47). London: Lawrence Erlbaum Associates Publishers.

House, Juliane (2003). "English as a Lingua Franca: A Threat to Multilingualism?" Journal of Sociolinguistics. 7 (4): 556-78.

House, Juliane (2013). "Developing Pragmatic Competence in English as a Lingua Franca: Using Discourse Markers to Express (Inter)Subjectivity and Connectivity". Journal of Pragmatics. 59: 57-67.

Huyhn, Tu T., Yoon J. Park and Anna Y. Chen (2010). "Faces of China: New Chinese Migrants in South Africa, 1980s to present." African and Asian Studies. 9 (3):286-306.

Hülmbauer, Cornelia, Heike Böhringer, and Barbara Seidlhofer (2008). "Introducing English as a Lingua Franca (ELF): Precursor and Partner In Intercultural Communication." Synergies Europe. 3: 25-36.

Hymes, Dell H (1968). "The Ethnography of Speaking”. In Readings in the Sociology of Language edited by Joshua A. Fishman, (Pp. 99-138). The Hague: Mouton. 
Jacquemet, Marco (2005). "Transidiomatic Practices: Language and Power in the Age of Globalization." Language \& Communication 25 (3): 257-277.

Jenkins, Jennifer (2006). "Current Perspectives on Teaching World Englishes and English as a Lingua Franca." TESOL Quarterly. 40 (1): 157-181.

Kachru, Braj B, ed. (1992) The Other Tongue. 2nd Edition. Urbana and Chicago: University of Illinois Press.

Kachru, Braj B (1996). "The Paradigms of Marginality." World Englishes. 15: 241-255.

Khosa, Risimati M. and Vivence Kalitanyi (2014). "Challenges in Operating MicroEnterprises by African Foreign Entrepreneurs in Cape Town, South Africa." Mediterranean Journal of Social Sciences 5 (10): 205-215.

Kraft, Kamilla (2017). Constructing Migrant Workers: Multilingualism and Communication in the Transnational Construction Site. PhD dissertation, Faculty of Humanities, University of Oslo, Norway.

Lønsmann, Dorte and Kamila Kraft (2018). "Language in Blue-Collar Workplaces." In Routledge Handbook of Language in the Workplace edited by Bernadette Vine, (Pp. 138-149). London: Routledge.

Liao, Wenhui and Qicai He (2015). "Tenth World Conference of Overseas Chinese: Annual International Symposium on Regional Academic Activities Report (translated)". The International Journal of Diasporic Chinese Studies. 7 (2): 85-9.

Massey, Doreen (1999). "Imagining Globalization: Power Geometries of Time-Space." In Global Futures: Migration, Environment and Globalisation edited by Avtar Brah, Mary J. Hickman and Mairtin Mac an Ghaill, (Pp. 27-44). Basingstoke: Macmillan.

Mesthrie, Rajend and Rakesh Bhatt (2008). World Englishes. Cambridge: Cambridge University Press.

Mufwene, Salikoko S. and Vigouroux, Cécile B, eds. (2008). Globalization and Language Vitality: Perspectives from Africa. London: Continuum Press.

Nickerson, Catherine (2005). "English as a Lingua Franca in International Business Contexts." English for Specific Purposes. 24 (4): 367-80.

Negretti, Raffaella and Miguel Garcia-Yeste (2015). "Lunch Keeps People Apart": The Role of English for Social Interaction in a Multilingual Academic Workplace.” Multilingua 34 (1): 93-118.

Otsuji, Emi and Alastair Pennycook (2010). "Metrolingualism: Fixity, Fluidity and Language in Flux." International Journal of Multilingualism. 7 (3): 240-254.

Otsuji, Emi and Alastair Pennycook (2011). "Social Inclusion and Metrolingual Practices." International Journal of Bilingual Education and Bilingualism. 14(4): 413-426.

Park, Yoon J (2009). Chinese Migration in Africa (China in Africa Project Occasional Paper No. 24). Braamfontein, South Africa: South African Institute of International Affairs. 
Pennycook, Alastair and Emi Otsuji (2014). "Market Lingos and Metrolingua Francas." International Multilingual Research Journal. 8 (4): 255-270.

Pölzl, Ulrike and Barbara Seidlhofer (2006). "In and on Their Own Terms: The 'Habitat Factor' in English As A Lingua Franca Interactions." International Journal of the Sociology of Language. 177: 151-176.

Rampton, Ben (2007). Linguistic Ethnography, Interactional Sociolinguistics and the Study of Identities (Working Papers in Urban Language and Literacies No. 43). London: Centre for Language Discourse and Communication, King's College London.

Rassool, Naz (2003). "Countering Globalization: Linguistic Diversity, Historical Complexities and the Re-Definition Of Language Possibilities." In Multilingualism in Global and Local Perspectives edited by Kari Fraurud and Kenneth Hyltenstam, (Pp. 31-46). Stockholm: Centre for Research on Bilingualism.

Roberts, Celia (2007). "Multilingualism in the Workplace." In Handbook of Multilingualism and Multilingual Communication edited by Peter Auer and Li Wei, (Pp. 405-422). Berlin: Mouton de Gruyter.

Sara, Sally (2013). "Thousands of Chinese entrepreneurs set up shop in South Africa." Interview by Thomas Oriti. The World Today, ABC News, June 14, 2013. Audio, o०:50. URL: http://www.abc.net.au/radio/programs/worldtoday/ thousands-of-chinese-entrepreneurs-set-up-shop-in/4754736.

Schegloff, Emmanuel, A (1987). "Analyzing Single Episodes of Interaction: An Exercise in Conversation Analysis." Social Psychology Quarterly. 50 (2):101-114.

Schegloff, Emmanuel, A (1988). "Goffman and the Analysis of Conversation. In Erving Goffman: Exploring the Interaction Order edited by Paul Drew and Anthony Wootton, (Pp. 89-135). Cambridge: Polity Press.

Schneider, Edgar, W (2020). English Around the World. 2nd Edition. Cambridge: Cambridge University Press.

Seidlhofer, Barbara (2009). "Common Ground and Different Realities: World English and English as a Lingua Franca." World Englishes. 28 (2): 236-45.

Seidlhofer, Barbara, Angelika Breiteneder and Marie-Luise Pitzl (2006). "English as a Lingua Franca in Europe." Annual Review of Applied Linguistics. 26:1-34.

Sewell, Andrew (2013). "English as a Lingua Franca: Ontology and Ideology." ELT Journal 67 (1): 3-10.

Sowden, Colin (2012). "ELF on a Mushroom: The Overnight Growth in English as a Lingua Franca." ELT Journal. 66 (1): 89-96.

Smit, Ute (2010a). "Conceptualising English as a lingua franca (ELF) as tertiary classroom language". Stellenbosch Papers in Linguistics. 39: 59-74.

Smit, Ute (2010b). English as a Lingua Franca in Higher Education. A Longitudinal Study of Classroom Discourse. Berlin: Mouton. 
Swain, Merrill (2006). "Languaging, Agency and Collaboration in Advanced Second Language Learning." In Advanced Language Learning: The Contributions of Halliday and Vygotsky edited by Heidi Byrnes, (Pp. 95-108). London: Continuum.

Vertovec, Steve (1999). "Conceiving and Researching Transnationalism." Ethnic and Racial Studies. 22 (2): 447-462.

Vertovec, Steve (2004). Trends and Impacts of Migrant Transnationalism (Centre on Migration, Policy and Society Working Paper No. 3). Oxford: Centre on Migration, Policy and Society, University of Oxford.

Wenger, Etienne (1998). "Communities of Practice: Learning as a Social System.” Systems Thinker. 9(5): 1-5. URL: https://thesystemsthinker.com/wp-content/uploads/ pdfs/ogo5oipk.pdf 


\section{Appendix 1: Transcription conventions}

\section{Speech production characteristics}

! exclamation, emphatic tone

$\uparrow \quad$ rising intonation

? indicates a question

(;) laughter

\section{Speech sequences:}

[] overlapping speech

[ onset of overlap

] termination of overlap

$=$ latching utterances 